\title{
PERDAMAIAN DAN KEMANUSIAAN DALAM PANDANGAN ISLAM
}

\author{
Supriyanto \\ STAI Mambaul Huda Surakarta \\ Supriyanto@gmail.com
}

\begin{abstract}
Abstrak
Perdamaian bukan hanya bertujuan untuk meredakan konflik atau ketegangan. Perdamaian memiliki dimensi personal dan sekali-gus dimensi sosial. Oleh karenanya, untuk menciptakan perdamaian dunia, mestinya setiap individu bisa berdamai terlebih dahulu dengan dirinya sendiri. Kedamaian individu itu tercermin pada p'kiran, ucapan, dan tindakan yang dilakukannya secara sadar dan konsisten. Hak Asasi Manusia (HAM) yang menekankan pada prinsip kebebasan dan perlindungan terhadap hak hidup ini, sangat vital kedudukannya dalam mencegah pembunuhan antar saudara sendiri dan mengembangkan kreativitas itulah peradaban manusia yang agung akan berlangsung dan berkembang terus-menerus, demokratisa-sipun akan lebih mudah diwujudkan. Tindakan preventif untuk mencegah dan mengakhiri perang, sebetulnyajuga bisa disandarkan pada upaya implementasi HAM pada masyarakat dunia.
\end{abstract}

\begin{abstract}
THE CONCEPT OF PEACE AND HUMANITY IN ISLAM. Peace is not only designed to defuse the conflict or tension. Peace has a personal dimension as well as dimension social. There fore, o create world peace, should any individual can peace in advance with the individual him self. Peace reflected in thought, word, and action did knowingly and consisten. Human right which emphasizes the principles of freedom and protection of the right of life, is fital in preventing the murder of his position among his own and develop the creativity of a great civilization that will last and evolve continously; democratically will easy to realized. The action preventive easier to prevent and end the war, actually also was bassed on effort to implement human right and the community.
\end{abstract}

Kata Kunci : Islam; Perdamaian; Kemanusiaan. 


\section{A. Pendahuluan}

Fenomena merajalelanya kekerasan dan pelanggaran hakhak asasi manusia yang semakin luas dan tidak mengindahkan etika moral dan kemanusiaan pada akhir-akhir ini semakin bermunculan. ${ }^{1}$ Hal ini nampak pada peristiwa tragedi WTC sebelas September 11 September 2001, Tragedi Bali 12 Oktober 2002, Operasi Militer di Aceh, Tragedi Bom di Hotel JW Marriot belum lama ini. Berkaitan dengan itu, maka wacana HAM layak kita angkat kembali ke permukaan.

Sikap perdamaian dan persaudaraan dalam menghargai hak-hak asasi manusia harus ditegakkan untuk mencapai persatuan dan kesatuan umat manusia. Sebab persatuan yang kuat akan menimbul-kan kekuatan dan menghindari kehinaan dan kelemahan. Dasar dan faktornya ada lima, yaitu agama, hubungan kekerabatan, persaudaraan, dan perbuatan baik. ${ }^{2}$ Agama Islam sangat menjunjung tinggi perdamaian dan kemanusiaan dalam rangka menjalin Ukhuwah Islamiah dan mencegah permusuhan sebab Rasulullah Saw berpesan kepada para sahabatnya untuk saling membantu dan tidak bermusuhan.

Rasulullah menyatakan dalam sabdanya: dengarkanlah kata-kataku dan camkanlah dalam hatimu! ketahuilah bahwa setiap muslim itu saudara bagi setiap muslim lainnya, bahwa karena itu sekarang kalian merupakan satu umat. Kata-kata yang amat mengesankan ini, yang diucapkan nabi dalam perjalanan hijrahnya yang terakhir (hajjatul wada) menuju Mekkah tidak lama sebelum wafatnya. Merangkum salah satu dari cita-cita Islam yang paling luhur dan tekanan ajarannya yang paling kuat. Persaudaraan Islam adalah suatu realitas. ${ }^{3}$

Muslim moderat percaya bahwa mengupayakan penghargaan dan penegakan hak-hak asasi manusia sebagai tujuan etis yang hendak dicapai merupakan perkara prinsip moral yang mendasar

${ }^{1}$ Ahmad Fuad Fanani, Islam Mazhab Kritis, Menggagas Keberagamaan Liberatif, (Jakarta: Buku Kompas, 2004), h. 110.

${ }^{2} \mathrm{Abu}$ al-Hasan Ali al-Bashr al-Mawardi, Etika Agama dan Dunia. Memahami Hakikat Beragama dan Berinteraksi di Dunia, (Bandung: Pustaka Setia, 2003), h. 123.

${ }^{3}$ Huston Smith, Agama-Agama Manusia, (Jakarta: Yayasan Obor Indonesia, 2004), h. 283-284. 
dan jauh dari konsep-universal yang keliru. Umat Islam sebagai mayoritas warga negara di seluruh dunia, tidak bisa menghindar dari fenomena di atas. Artinya umat Islam harus juga melindungi pelaksanaan HAM bagi seluruh penganutnya. Maka, hak hidup dan kebebasan wajib diakomodir oleh umat Islam, sebab, hal itu mendapatkan pembenaran dan landasan teologis dari al-Qur'an dan Sunnah Nabi sebagai sumber pokok ajaran Islam.

Di bangun di atas tradisi Islam, kaum moderat mengemukakan bahwa minimal semua manusia punya hak, harga diri dan kebebasan. Keyakinan orang-orang moderat terhadap demokrasi dan hak-hak asasi manusia diawali dengan premis bahwa penindasan adalah pelecehan besar-besaran terhadap Tuhan dan Manusia. AlQur'an mendeskripsikan para penindas sebagai perusak bumi dan juga menggambarkan penindasan sebagai bentuk penghinaan terhadap Tuhan. Dalam pemikiran moderat, diakui bahwa semua manusia berhak atas harga diri. Al-Qur'an dengan jelas menyatakan bahwa Tuhan telah menganugerahkan harga diri pada setiap manusia. ${ }^{4}$

Apabila yang dimaksud dengan demokrasi adalah persamaan dalam segala sesuatu, itu hanya salah satu dongeng atau hayalan yang tidak akan pernah ada di dunia ini, baik dalam dunia binatang maupun para manusia baik di kota ataupun di desa. Allah SWT tidak menyamakan manusia dalam satu macam di antara mereka, tidak juga dalam kekuatan kecerdasan tipu daya, rezeki serta nasib mereka. Perbedaan tingkatan atau kasta yang mendominasi masyarakat yang biasa kita kritik bahkan mengecamnya adalah sistem yang sebenarnya terdapat hampir di semua negara. bangsa rusia yang demokrasinya telah mencapai batas kekacauan mempunyai pemimpin dan yang dipimpin, dan yang unggul dikarenakan kecerdikan dan kekuatannya, sedang yang dikuasai diberikan kebodohan dan kelemahannya. Begitu juga Inggris diantara mereka terdapat raja para bangsawan serta masyarakat awam. ${ }^{5}$

${ }^{4}$ Khaled Abou el-Fadi, Selamatkan Islam Dari Muslim Puritan, (Jakarta: Pustaka Serambi, 2006), h. 221.

${ }^{5}$ Abdul Halim Mahmud, Tasawuf di Dunia Islam, (Bandung: Pustaka Setia, 2002), h. 295. 


\section{B. Islam dan Perdamaian Global}

Pada waktu yang sama setiap penganut agama berkeyakinan bahwa agamanya mengajarkan tentang perbuatan praktis, berarti bahwa agama mengandung unsur yang berbeda dalam Lingkungan, daya dan kemampuan manusia untuk melaksanakan dengan sendirinya yang bernilai manusiawi karena ia berada pada diri manusia itu sendiri. Agar suatu ajaran agama berada dalam daya dan kemampuan manusia untuk melaksanakannya, maka manusia harus membawa ke dalam dirinya pada lingkungan yang menjadi batas kemampuannya. Jadi jelas ada dimensi atau unsur kemanusiaan dalam usaha memahami ajaran agama. Pernyataan adanya unsur manusiawi dalam memahami ajaran agama untuk mengamalkan adanya intervensi manusia dalam urusan yang menjadi hak prerogratif Tuhan itu. ${ }^{6}$

Al-Qur'an sejak awal menegaskan perihal visi transformatif dan liberatif untuk kemanusiaan. Ayat-ayat mengawali misi penurunan al-Qur'an dengan mengadakan revolusi teologis. Revolusi teologis ini mengartikulasikan subsiansinya melalui jargon "Tauhid" yang menegaskan seluruh sesembahan hanya Allah. Tauhid ini juga menegaskan semangat egalitarianisme sebagai simbol perlawanan terhadap perbudakan dan kejahatan kemanusiaan yang terjadi di Makkah.Sedangkan ayat-ayatMadaniyah mengindikasikan semangat revolusi sosiologis terhadap tatanan dan struktur sosial kehidupan masyarakat dengan menjadikan keadilan dan kemakmuran sebagai doktrin sandaran.

Sebetulnya, hampir dipastikan bahwa semua negara dan agama sepakat agar warga dan umatnya menghindari tindak kekerasan. Semuanya pasti setuju dengan terciptanya perdamaian dunia yang telah lama dinanti-nantikan. Ideologi perang dan kekerasan di masa lalu, terbukti banyak menimbulkan kebangkrutan dan kemunduran peradaban. Oleh karena itu, isu terorisme memojokkan umat beragama dan negara berkembang, haruslah dikaji dan dikritisi secara mendalam.

Ibadah atau keberagamaan tidak hanya ditujukan sebagai

${ }^{6}$ Nurcholish Madjid, Islam dan Doktrin dan Peradaban, Sebuah Telaah Kritis tentang Keimanan, Kemanusiaan dan Kemodernan, (Jakarta: Yayasan Wakaf Paramadina, 1992), h. 328-329. 
pemuas batin dan pengguguran kewajiban pada Tuhan, namun nilai-nilai ibadah hendaknya ditransformasikan juga pada perilakunya sehari-hari. Sehingga ibadah-ibadah seorang hamba kepada Tuhan-nya bukan merupakan ritus yang hampa makna. Berkaitan dengan perdamaian, sesungguhnya ajaran Islam menjunjung tinggi dalam aspek ritual dan sosialnya nilai-nilai kebenaran, keadilan kerakyatan, serta perdamaian. Bahkan, Islam sendiripun turun pertama kali dengan misi rahmatan lil 'Alamin (karunia bagi seluruh alam). Artinya, Islam sejak awal menekankan pemeluknya untuk menghargai pemeluk agama lain dan mengakuinya sebagai mitra dalam penciptaan perdamaian. Selain itu, kata Islam yang berakar kata sama dengan salam pun, maknanya adalah kedamaian. Maka, setelah manusia membuktikan pengabdiannya lewat ibadah kepada Allah, mereka juga harus mempraktekkannya dengan menebarkan perdamaian pada semua umat manusia. Untuk menerangkan bagaimana Islam menjawab pertanyaan tentang perdamaian, cukuplah dengan menerangkan beberapa kenyataan dan fakta yang terdapat dalam Islam. Perdamaian dan Islam berasal dari salah satu akar kata yang sama sehingga boleh juga dikatakan bahwa Islam adalah sinonimnya dari perdamaian.

Salah satu dari sembilan puluh sembilan Asma Allah adalah as-Salām (Maha Damai). ${ }^{7}$ Setiap lafazh (kata) yang diucapkan umat Islam dalam setiap shalat yang lima kali sehari semalam adalah kata-kata perdamaian. Ucapan pertama ketika selesai dari salat adalah "salam" (perdamaian). Ketika umat Islam saling berjumpa pun mengucapkan ucapan "salam" (perdamaian). Demikian juga, kata sifat dari muslim artinya perdamaian dan surga dalam Islam adalah suatu tempat yang damai (Dārus Salām). Semua ini memperlihatkan betapa mendasar dan kuatnya pengertian perdamaian dalam Islam. Setiap orang yang mencapai Tuhan melalui Islam, sama sekali tidak ada kecewa untuk mendapatkan kedamaian bersama Tuhannya, Allah aza wa jalla, damai dengan dirinya, dan damai bersama orang-orang yang mau mengikutinya.

${ }^{7}$ Abdullah Zakiy al-Kāf, Islam Cahaya Dunia Menuju Keselamatan Akhirat, (Bandug: Pustaka Setia, 2002), h. 123. 
Berperang pada pengertian ini, jelas bahwa manusia akan ditempatkan pada tempat yang paling mulia di dunia dan menjalani hidup ini dalam keislaman. Dengan demikian, yang telah mendapatkan jalan yang benar dan berprinsip tidak akan gagal dalam hidupnya, akan mendapatkan kemuliaan manusia, memperoleh persamaan antara satu dan yang lain, menikmati rasa persaudaraan yang universal, dan menciptakan perdamaian yang abadi. Al-Qur'an lebih mengutamakan perdamaian dari pada perang selagi perdamaian tersebut dapat dipertahankan. Akan tetapi, bila tidak ada jalan damai untuk membela agama, kehidupan, dan tanah air, tindakan akhir yang tidak dapat dihindarkan adalah perang.

Perlu untuk diingat (1) sesungguhnya kitab suci al-Qur'an mengajak kaum muslimin pada sifat-sifat yang mulia dalam segala hubungan dan pergaulan. Namun, bila sifat yang mulia tidak dapat dipertahankan lagi, sudah semestinya bila kita menghadapi kenyataan yang sesuai dengan situasi dan kondisi. Sesungguhnya al-Qur'an pun mengajak perdamaian dalam arti mengutamakan perdamaian, namun musuh-musuh Islam tidak mau menerima, kecuali peperangan. (2) Al-Qur'an menyebutkan bahwa surga itu dinamakan dār as-salām sebagaimana dinyatakan dalam QS. al-An'am [6]: 127; (3) Allah 'Azza wa Jalla telah berfirman kepada Rasulullah SAW, agar dirinya condong pada perdamaian sebagaimana dinyatakan dalam Q.S. al-Nisa [4]: 99.

Walaupun telah diadakan pertemuan dan dialog dengan tanpa kekerasan namun masih timbul aksi kekerasan tahap peace keeping, belum mencapai tahapan peacemaking, apalagi paece building artinya pertemuan dan dialog baru langkah menghentikan konflik, tetapi belum cukup menjamin perdamaian yang lebih permanen. ${ }^{8}$ Padahal, selain penghentian konflik penegakan hukum dan rehabilitasi sosio-ekonomi, diperlukan upaya pembangunan perdamaian (peace building) melalui pendidikan perdamaian (peace education) demi mencapai suatu perdamaian permanen dan untuk mencegah munculnya kembali konflik etnis dan agama di wilayah suatu negara.

Pendidikan perdamaian adalah proses penyadaran untuk

${ }^{8}$ Muhamad Ali, Teknologi pluralis Multicultural menghargai kemajemukan, menjalin kebersamaan, (Jakarta: Buku Kompas, 2003), h. 163. 
mengubah pandangan hidup dari budaya kekerasan menuju budaya perdamaian dan non kekerasan (culture of peace), mengembangkan pemahaman kritis mengenai akar-akar konflik dan kekerasan, dan memberdayakan masyarakat untuk mengambil aksi personal dan sosial. Dengan demikian, pendidikan perdamaian mendidik masyarakat tentang kekuatan perdamaian dan mengubah pola pikir dan perilaku kekerasan yang mengitari mereka, serta mengubah cara - cara kekerasan dengan kesadaran perdamaian yang menghargai kerja sama, kebaikan, kejujuran, kasih sayang, toleransi, kedermawanan dan keadilan.

Jika tidak ada proses pendidikan yang konsisten bagi transformasi budaya kekerasan menuju budaya perdamaian yang meningkatkan kesadaran dan memberdayakan individu dan kelompok masyarakat, maka akan terjadi kemungkinankemungkinan akan membawa cara-cara yang tidak mendamaikan, dan ketidak-langgengan proses perdamaian.

Di negeri kita pembangunan perdamaian (peace building) sangat penting dilakukan, karena masyarakat kita sering dipertontonkan dengan adegan kekerasan selama lebih dari tahun orde baru. Masyarakat terus dididik bersikap keras, vandalistik, dan anarkis. Seolah tidak ada cara menyelesaikan kekerasan kecuali dengan kekerasan (violence by violence). Masyarakat diajarkan modelmodel budaya kecurangan, korupsi, dan kekerasan. Familisme, nepotisme, dan kekerabatan berdasar etnis dan agama juga dibiarkan berkembang, dan sering dianggap sebagai mekanisme pemecahan masalah.

Sering, musyawarah untuk mufakat hanya lip service. Rezim memiliki kekuasaan untuk mengancam, memaksa, dan merampok hak-hak rakyat. Money is everything dibudayakan. Mayoritas diajarkan menghegemoni makna dan kekuasaan. Masing-masing pihak yang bertikai berupaya menyamakan wilayah mereka dan mendominasi wilayah itu secara ekonomi, politik, dan budaya dengan menggunakan idiom-idiom etnis dan agama. Dan, kepentingan kelompok-kelompok agama meniadakan konflik etnis dan agama semakin complicated. Padahal, masyarakat yang hidup dalam konteks yang otoritarian, mengancam, dan atau menghukum cenderung berperilaku sangat agresif. Sebaliknya, jika masyarakat dididik 
dengan pemecahan masalah dan keterampilan resolusi konflik maka mereka cenderung lebih bijak dalam berperilaku sosial.

\section{Islam dan Visi Kesetaraan Kemanusiaan}

Dalam ajaran Islam tentang awal kemanusiaan dinyatakan bahwa kemanusiaan dimulai dengan sosok Adam as yang diciptakan Allah swt dengan sebaik-baiknya, dan di dalamnya ditiupkan dari ruh-Nya. ${ }^{9}$ Allah swt menciptakan agar manusia menjadi khalifah Allah swt dalam membangun bumi dan meramaikannya. Manusia kemudian berkembang biak dari asal Adam as dan isterinya Hawa maka perkembangan manusia datang dari sosok manusia yang satu.

Dalam kerangka kesatuan ini, terjadi plurlisme dan perbedaan antara ras, warna, umat, bangsa, kabilah, lidah, bahasa, nasionalisme, dan perbedaan. Dan, seterusnya terdapat bermacam dan beragam pluralisme dalam rangka kemanusiaan yang satu, yang seluruhnya kembali dan menisbatkan diri keadaan-Nya. Manusia diciptakan Tuhan dengan bentuk yang sebaik-baiknya, yang kita kenal sebutannya dengan istilah "ahsanul khuluq" yakni ciptaan yang terbaik. ${ }^{10}$ Islam diturunkan pertama kali pada masyarakat Arab yang tidak hampa sejarah dan kebudayaan. Waktu itu, banyak agamaagama, suku, dan bermacam kebudayaan masyarakat Arab yang tidak bisa disatukan begitu saja. Jadi, sejak awal Islam menegaskan bahwa dirinya adalah rahmatan lil 'àlamin (rahmat untuk seluruh alam). Islam tidak membedakan suku-suku atau kulit karena ia adalah agama yang membawa pencerahan kepada seluruh umat manusia.

Al-Qur'an menawarkan konsep antropologis yang sangat dibutuhkan sebagai titik tolak dalam membangun visi pendidikan Islam yang diharapkan dapat menyelesaikan persoalan filosofis yang telah berlarut-larut yang merupakan akibat masih kabumya pandangan kemanusiaan dalam pendidikan Islam. Al-Qur'an begitu gamblang berbicara tentang manusia, di samping tema-tema besar

${ }^{9}$ Muhammad Imarah, Islam dan Pluralisme, Perbedaan dan Kemajemukan Dalam Bingkai Persatuan, (Jakarta: Gema Insani Press, 1999), h. 138.

${ }^{10}$ Syabirin Harahab, Manusia Paripurna, (Semarang: Pustaka Nizamiyah, 2003), h. 87. 
seperti mengenai persoalan teologis dan kosmologis. al-Qur'an secara kategorikan mendudukkan manusia kedalam dua fungsi pokok yaitu sebagai 'abdullāh (hamba Allah) dan sebagai khalifah fi al-ard (wakil tuhan di muka bumi). ${ }^{11}$

Menurut Muhammad Husain Haykal prinsip persamaan antar manusia dipandang sebagai prinsip dasar ketiga bagi pengelolaan masyarakat. Dua prinsip lainnya adalah prinsip tauhid dan sunatullah. Prinsip tauhid mengajarkan bahwa semua manusia sama kedudukanya di hadapan Allah swt dan atas mereka berlaku segala sunatullah yang adil. Jadi, tidak ada perbedaan antara satu dengan yang lainnya, tidak ada kelebihan bagi orang Arab atas non Arab selain kualitas takwanya. Sementara itu, prinsip sunatullah mengajarkan bahwa alam semesta, termasuk manusia, tunduk pada sunnatullah. Dengan demikian, paham ini menyimpulkan bahwa semua manusia itu sama yaitu tunduk kepada hukum-hukum yang tetapkan Allah swt di alam ini.

Dalam prinsip persamaan ini, Haikal menegaskan kembali bahwa bila semua manusia sama, sudah pasti semua muslim pun sama. Bahkan, ia bersaudara satu dan lainnya dengan hak dan kewajiban yang sama. Jadi, semua muslim itu bersaudara dan mereka harus mencintai satu sama lain. Tidak sempurna iman seseorang sebelum ia mencintai saudaranya seperti ia mencintai dirinya sendiri. Oleh karena itu, wajar bila prinsip dianggap sebagai salah satu prinsip kehidupan bermasyarakat yang asasi dalam Islam.

Beberapan ayat yang berbicara tentang persamaan ini antara lain Q.S. al-Hujurat (49) ayat 13 yang berbunyi: "Wahai manusia, sesungguhnya Kami menciptakan kalian dari seorang laki-laki dan seorang perempuan serta menjadikan kalian berbangsa-bangsa dan bersuku-suku supaya kalian saling kenal-mengenal (hidup rukun dan damai). Sesungguhnya orang yang paling mulia di antara kalian disisi Allah adalah orang yang paling takwa di antara kalian. Sesungguhnya Allah Maha Mengetahui lagi Maha Mengenal". Turunnya ayat al-Quran diatas merupakan sebuah langkah yang spektakuler dan revolusioner. Sebab, ia bukan saja mengubah

${ }^{11}$ Tobroni \& Syamsul Arifin, Islam Pluralisme Budaya dan Politik: Refleksi Teologi Untuk Aksi Dalam Keberagamaan dunia Pendidikan, (Yogyakarta: SIPRES, 1994), h. 117. 
tatanan masyarakat pada waktu itu, tetapi ia juga mendekonstruksi pilar-pilar peradaban, kebudayaan, dan tradisi yang diskriminatif dan patriarkis yang telah lama dipraktiskan masyarakat.

Pada masa pra-Islam, harga perempuan sangat rendah. Mereka dianggap barang atau benda yang dapat diperlakukan apa saja bahkan seringkali orang menganggap bahwa melahirkan perempuan dipandang sebagai hal yang memalukan. Oleh karena itu, pembunuhan anak perempuan dianggap sesuatu yang wajar dan pantas. Oleh Islam praktik - praktik diskriminatif dan tidak manusiawi dilarang. Islam secara bertahap mengembalikan kembali otonomi sebagai perempuan sebagai manusia merdeka dan mulia.

Prinsip persamaan dalam Q.S. al-Hujrat: 13 di atas juga erat kaitannya dengan penegasan Allah dalam Q.S. an-Nahl (16): 97 yang berbunyi. Pada ayat ini, tampak ajaran Islam tidak membedakan antara lelaki dan perempuan. Pembedaan didasarkan pada amal saleh (perbuatan baik) yang dilakukannya dengan sadar. Dalam perbuatan itu, juga dijelaskan Allah akan konsekuensi dan resiko yang diperoleh perilakunya. Para pemikir feminis kontemporer bahwa ketimpangan itu, selain disebabkan oleh kultur dan kondisi sosial yang memihak laki-laki, juga sering diilustrasikan oleh penafsiran surat an-Nisa (4) ayat 34 yang berbunyi,"laki-laki adalah qawwām mereka atas sebagian yang lain dan karena mereka (lakilaki) memberikan nafkah dari harta mereka."

Secara umum, para ahli tafsir berpendapat bahwa superioritas laki-laki adalah sebuah kemutlakan. Kelebihan lakilaki dari perempuan oleh para ahli tafsir dinyatakan terletak pada watak dan fisiknya. Ar-Razi dalam tafsirnya misalnya, mengatakan bahwa kelebihan laki-laki atas perempuan meliputi dua hal ilmu pengetahuan, pikiran, akal dan kemampuan (al-qudrah). Artinya, akal dan pengetahuan laki-laki melebihi akal perempuan dan bahwa pekerjaan keras laki-laki lebih sempurna.

At-Tabari juga menjelaskan hal senada bahwa qawamun adalah penanggung jawab dalam mendidik dan membimbing istri agar menunaikan kewajibannya kepada Allah maupun pada suami. Selanjutnya, az-Zamakhasyari juga menekankan bahwa kata itu berarti kaum laki-laki berkewajiban melaksanakan amar ma'ruf 
nahi mungkar kepada wanita sebagaimana penguasa kepada rakyatnya.

Semua penafsiran yang mendudukan perempuan pada posisi inferior di atas, pada massa sekarang tidak dapat di pertahankan lagi, mengingat tidak setiap laki-laki lebih berkualitas dari pada perempuan. Fakta sejarah juga membuktikan sekarang banyak perempuan yang memiliki potensi lebih bahkan bisa melakukan peran-peran yang di jalankan laki-laki. Perempuan dewasa sekarang ini banyak yang menjadi wanita karir, mengambil peran kepemimpinan baik pada urusan domestik maupun publik.

Karakteristik yang menjadi hal dasar argumen superiotas laki-laki bukanlah suatu yang bersifat baku dan pasti, tetapi lebih bersikap kontekstual dan menyejarah. Oleh karena itu, penafsiran al-Quran yang tidak bias gender harus di rumuskan kembali. Hal ini di lakukan untuk mengembalikan pemahaman al-Quran tentang perempuan yang biasa kepada pemahaman al-Quran yang menjunjung tinggi prinsip persamaan dan keadilan.

Menurut Fazlur Rahman, penafsiran al-Quran Surat anNisa ayat 34 di atas bukan diletakan pada posisi hakiki (baku), tetapi lebih bersifat fungsional. Maksudnya, apabila sang istri di bidang ekonomi dapat berdiri sendiri, keunggulan suaminya akan berkurang karena sebagai seorang manusia ia tidak memiliki keunggulan dibandingkan dengan intinya.

Sementara Asghar Ali Enginer berpendapat bahwa penafsiran ayat harus di pahami saat kondisi ayat tersebut diturunkan. Menurutnya, kata qawwamun dalam ayat tersebut bukanlah perintah, namun sebuah posisi yang konstektual pada zamanya. Jadi, pemahaman al-Quran surat an-Nisa ayat 34 di atas haruslah di hubungkan dengan ayat-ayat lain yang menegaskan persamaan umat manusia.

Dari ayat-ayat yang telah di sebutkan, tampak bahwa ajaran persamaan dalam Islam mencakup dua askep sekaligus yaitu kerohanian dan kemasyarakatan. Aspek kerohanianya terletak pada penyadaran manusia akan jati dirinya sebagai hamba Allah SWT lewat ibadah yang berujung pada tingkat takwa sedangkan aspek kemasyarakatan atau sosialnya terletak pada penyadarannya bahwa manusia diharapkan berbuat baik (amalan shalihan) dengan 
saling membantu dan menolong pada sesamanya. Persaudaraan berdasarkan prinsip persamaan ini akan lebih memudahkan manusia untuk melakukan sikap saling menghargai, terbuka, dan membantu berdasarkan prinsip al-Quran.

Prinsip persamaan kedudukan manusia yang diajarkan Islam sebagaimana telah dipaparkan, memiliki pengertian yang sangat luas. Paham persamaan itu mancakup kesetaraan laki-laki dan perempuan dan juga pada muslim dan non-muslim persamaan itu juga meliputi suatu hak persamaan hak dalam bidang politik, ekonomi, sosial, budaya dan sebagainya. Perbedaan kulit, ras, perolehan rejeki, jenis kelamin, umur hendaknya justru di jadikan sarana untuk berhubungan dan tolong-menolong dengan lainnya. Perbedaan itu haruslah tidak menjadi sebuah perbedaan yang berujung pada perilaku diskriminatif dan menindas. Apabila perilaku diskriminatif itu masih banyak muncul dalam kehidupan sehari-hari menjadi tugas kita semua untuk mencegahnya.

Prinsip persamaan saat ini merupakan salah satu pilar penegak demokrasi, tentunya selain kebebasan dan persaudaraan. Dalam prinsip persamaan, semua manusia mempunyai hak untuk berpartisipasi dalam urusan publik atau kontrol kebijakan pemerintah. Hal ini juga berkaitan erat dengan penegak hak asasi manusia (HAM) karena dengan prinsip persamaan manusia lebih mudah menjalankan kebebasan dan bertanggungjawab atas perbuatannya.

\section{Penutup}

Berdasarkan paparan di atas pada saat ini umat Islam yang dijelaskan di atas, maka pada saat ini umat Islam perlu memainkan peranan yang signifikan, khususnya dalam penciptaan perdamaian. Dan berusaha mewujudkan wajah Islam yang damai dan menyejukkan. Hal itu dilakukan dengan mencari landasan teoritis, praktis dan penelitian yang mendalam terhadapnya. Sehingga apologi dan sikap yang subyektif dapat dihindari sekecil mungkin. Dengan wajah Islam yang penuh perdamaian juga citacita demokrasi Indonesia segera dapat terwujud, krisis segera dapat terentaskan dan harga diri bangsa kembali bermartabat. Prinsip persamaan pada masa sekarang merupakan salah satu pilar penegak 
demokrasi, tentunya di samping kebebasan dan persaudaraan. Dalam prinsip persamaan, semua manusia mempunyai hak setara untuk berpartisipasi dalam urusan publik atau kontrol kebijakan pemerintah. Hal ini juga berkaitan erat dengan penegakan hak asasi manusia (HAM). []

\section{Daftar Pustaka}

Ali, Muhamad, Teknologi Pluralis Multikultural Menghargai Kemajemukan, Menjalin Kebersamaan, Jakarta: Buku Kompas, 2003.

El-Fadl, Abou Khaled, Selamatkan Islam dari Muslim Puritan, Jakarta: Pustaka Serambi, 2006.

Fuad, Ahmad, Islam Mazhab Kritis, Menggagas Keberagaman Liberatif, Jakarta: Buku Kompas, 2004.

Halim, Mahmud Abdul, Tasawuf di Dunia Islam, Bandung: Pustaka Setia, 2002.

Harahap, Syabirin, Manusia Paripurna, Semarang: Pustaka Nizamiyah, 2003.

Hasan, Abu, Etika Agama dan Dunia. Memahami Hakikat Beragama dan Berinteraksi di Dunia, Bandung: Pustaka Setia, 2003.

Imarah, Muhammad, Islam dan Pluralisme:Perbedaan danKemajemukan Dalam Bingkai Persatuan, Jakarta: Gema Insani Press, 1999.

al-Kaaf, Abdullah Zakiy, Islam Cahaya Dunia Menuju Keselamatan Akhirat, Bandung: Pustaka Setia, 2002.

Madjid, Nurcholish, Islam Doktrik Dan Peradaban. Sebuah Telaah Krilis Tentang Keimanan, Kemanusiaan dan Kemodernan, Jakarta: Yayasan Wakaf Paramadina, 1992.

Smith, Huston, Agama-Agama Manusia, Jakarta: Yayasan Obor Indonesia, 2004.

Tobroni \& Arifin, Syamsul, Islam Pluralisme Budaya dan Politik :Refleksi Teologi Untuk Aksi Dalam Keberagamaan Dan Pendidikan, Yogyakarta: Sippres,1994. 
Supriyanto

halaman ini bukan sengaja dikosongkan 